\title{
Meta
}

Journal des traducteurs

Translators' Journal

\section{The Role of the Communicative Approach in the Development of Terminology}

\section{Ángela Campo et Monique C. Cormier}

Volume 50, numéro 4, décembre 2005

Pour une traductologie proactive - Actes

For a Proactive Translatology — Proceedings

Por una traductología proactiva - Actas

URI : https://id.erudit.org/iderudit/019913ar

DOI : https://doi.org/10.7202/019913ar

Aller au sommaire du numéro

Éditeur(s)

Les Presses de l'Université de Montréal

ISSN

0026-0452 (imprimé)

1492-1421 (numérique)

Découvrir la revue

Citer cet article

Campo, Á. \& Cormier, M. C. (2005). The Role of the Communicative Approach in the Development of Terminology. Meta, 50(4). https://doi.org/10.7202/019913ar
Résumé de l'article

Du point de vue de la méthodologie du programme de recherche scientifique de Lakatos, l'émergence de nouvelles approches terminologiques ne signifie pas qu'on doive privilégier une approche plutôt qu'une autre. Ces approches doivent plutôt être vues comme celles qui structurent la terminologie comme programme de recherche scientifique. De façon spécifique, nous nous proposons d'explorer le rôle de la théorie communicative de la terminologie dans le développement de la discipline. L'heuristique de l'approche l'ensemble de règles conçues pour augmenter les possibilités de résoudre un problème dans la discipline - nous permettra de déterminer comment l'approche communicative contribue au développement du programme de recherche terminologique. 


\title{
The Role of the Communicative Approach in the Development of Terminology
}

\author{
ÁNGELA CAMPO \\ University of Montreal, Montreal, Canada \\ angela.campo@umontreal.ca \\ MONIQUE C. CORMIER \\ University of Montreal, Montreal, Canada \\ monique.cormier@umontreal.ca
}

\begin{abstract}
RÉSUMÉ
Du point de vue de la méthodologie du programme de recherche scientifique de Lakatos, l'émergence de nouvelles approches terminologiques ne signifie pas qu'on doive privilégier une approche plutôt qu'une autre. Ces approches doivent plutôt être vues comme celles qui structurent la terminologie comme programme de recherche scientifique. De façon spécifique, nous nous proposons d'explorer le rôle de la théorie communicative de la terminologie dans le développement de la discipline. L'heuristique de l'approche - l'ensemble de règles conçues pour augmenter les possibilités de résoudre un problème dans la discipline - nous permettra de déterminer comment l'approche communicative contribue au développement du programme de recherche terminologique.
\end{abstract}

\begin{abstract}
The emergence of new terminology approaches does not mean that one approach should be used in preference to a previous one. These approaches suggest the structuring of terminology as a scientific research program, as described in Lakatos's Methodology of Scientific Research Programmes. Specifically, we propose to explore the role of the Communicative Theory of Terminology in the development of the discipline. The heuristic of this approach, the set of rules intended to increase the probability of solving a problem within the discipline, will allow us to determine how the communicative approach contributes to the development of the research program.
\end{abstract}

\section{MOTS-CLÉS/KEYWORDS}

linguistics, terminology, Theory of Terminology, Communicative Theory of Terminology, Scientific Research Program

\section{Introduction}

In the last fifteen years there has been a growing interest in reexamining traditional terminology. This is evidenced by the new theoretical proposals that are being presented for specific approaches to terminology, such as the socioterminology, sociocognitive, text-based and communicative approaches. Terminology scholars are interested in larger theoretical structures that unify and guide terminology research. For instance, Budin (2001) offers an account of the advanced level of analysis currently achieved in the field of terminology theory. He presents a critical evaluation of state-of-the-art terminology theory from the perspective of the philosophy of science and closely related fields, such as the sociology of science and epistemology. His purpose is to take a critical and comparative view of terminology theory (Budin 2001: 8). For this analysis, Budin chose to work on a "coordinative comparison of theories" because this methodology provides the means: 
solution or an explanation where the others do not, so that in the end a cluster of theories emerge that support each other and add to each other and that can be used in a combined way (Budin 2001: 13).

In the report on the concluding round table of the Second International Terminology Conference CIT 2003, Terminology: The State of the Theories Blanchon (2004), the group:

[...] highlighted the fact that theoretical approaches that have often been considered as contradictory are in reality as complementary as the users needs and should be reconciled, especially in view of the current and future evolution of terminology linked with the ever growing importance of information technologies. Thus onomasiology and semasiology, linguistics and terminology, must reunite and the different countries, different kinds of research, different kinds of practices, must share their knowledge in order to take advantage of an ambitious and robust theory, and provide continuous feedback. (Blanchon 2004: 340).

In the same conference "Roger Goffin too stressed the fact that the theory of terminology is not one but many" (Blanchon 2004: 337-338). This paper follows the same lines and has two objectives: first, to present terminology as a scientific research program, in Lakatos's terms, and second to focus on the contribution of the communicative approach to terminology. Specifically, it will concentrate on how the Communicative Theory of Terminology (CTT) is contributing to the development of the discipline.

\section{Terminology as a Scientific Research Program}

Imre Lakatos (1970 and 1978) outlined a theory of scientific development that bears similarities to those of both Karl Popper (1962) and Thomas Kuhn (1962) and explains the role of criticism in that development. Thus, in order to describe the development of a discipline, it is better to consider the different theories within that discipline as elements of the structure of the program. According to Lakatos's "scientific research programme" concept, academic fields, including the field of terminology, need to have theories that are broad enough to preserve some kind of coherence within the field. In this sense, knowledge does not necessarily grow when one theory seems to be more successful than others. Instead, he maintained, scientific growth is better understood in terms of a scientific research program (Lakatos 1970: 47).

For terminology, this general scheme of Lakatos is particularly attractive because the discipline can be analyzed as a set of theories and approaches, what Lakatos (1978: 33) considers "[...] a series of theories rather than isolated theories." The scientific research program supposes a three-dimensional structure composed of a "hard core", a "protective belt", and a "heuristic". These three layers of dialectic organization constitute the terminology research program. The "hard core" includes the basic, essential assumptions of the program; it comprises everything that is fundamental to its existence (Lakatos 1978: 48). In our adaptation of Lakatos's work, the General Theory of Terminology (GTT) constitutes the hard core of the program because it provides the essential framework of the discipline and contains the general theoretical statements that play a legitimate role in the historical development of this discipline. Therefore, this hard core can turn into a set of guidelines or a set of heuristic principles for the development of the research program. The hard core has a protective belt called the "negative heuristic". It consists of the tacit and implicit assumption that the hard core of the program must not be modified. The most external layer of the scientific research program is known as the "positive heuristic", which is represented by the general directives used to explain well-known phenomena or predict new ones (Lakatos 1978: 4952).

The distinctive characteristic of the terminological research program is its hard core. It is shaped by general theoretical hypotheses that constitute the base from which the program is developed. By using the "program" concept, the discipline of terminology will benefit from these different approaches and theories which tend to cluster and support each other in various ways; they also provide historical continuity despite changes in the status of testable theories. 


\section{The Communicative Theory of Terminology (CTT)}

As an alternative to the postulates of the General Theory of Terminology (GTT), Cabré (1999) brought together a series of reflections that are the foundation of the Communicative Theory of Terminology. The CTT is mainly characterized by a linguistic approach to gathering concepts, such as terminological variation, harmonization, term usage in texts, terminological application design, linguistic engineering for terminology work and research. The CTT requires linguistic variation to be contemplated from the theoretical and methodological points of view. It is an interdisciplinary approach enriched by the theory of knowledge, theory of communication, and theory of language. It stems from the insufficiencies of the GTT and is still in a developmental stage. Finally, it assumes that communication is not uniform because there is nominative and conceptual variation.

The CTT's principles can be summarized as follows (Cabré 1999: 122-124, 131-133). Terminology is an interdiscipline, which enriches itself from the theory of knowledge, the theory of communication and the theory of language. The objects of study are the terminological units (TU) themselves, which are part of natural language. Terms are lexical units that are activated by their pragmatic conditions of adjustment to a given type of communication. They are also units of form and content in which the content is simultaneous to the form. Concepts in a given specialized area maintain different types of relationships with each other. The value of a term is established by the place it occupies in the conceptual structure of a given field according to the criteria established in a terminology project. The objective of theoretical terminology is to provide formal, semantic and functional descriptions of units that can acquire terminological value and the objective of applied terminology is to compile the units of terminological value. Lastly, the purposes for which units with terminological value that are used in a field are compiled and analyzed are very diverse and allow many applications.

\section{The CTT and Terminology as a Scientific Research Program}

Based on the "scientific research programme" concept proposed by Lakatos (1970 and 1978), the following is a brief analysis of the contribution of the CTT to the development of terminology as a research program. From this point of view, the function of specific theories of terminology is to help structure the scientific research program. In the case of the CTT, the theory is guided in terms of the positive heuristic.

Since many theoretical and practical projects have arisen, as well as approaches in terminology, the question is what guides the growth of this discipline. Lakatos's methodology contains the notion of "heuristic progress", meaning the successive modifications of the protective belt and the dramatic signs of empirical progress (Lakatos 1978: 179). The communicative approach can be seen as a positive heuristic because, from the viewpoint of linguistics and based on a descriptive approach, the CTT can make novel predictions and provide answers and solutions to new terminological situations and phenomena. The question is how does the CTT contribute to the program? And what, exactly, is its contribution? First, it provides access to the three structural levels of the program. The initial contact of any theory or approach with the program occurs with new experimental data which:

1) are in agreement with the main historical facts observed, in which case the hard core of the program is reinforced;

2) register some differences but only at the level of the protective belt which is easily modifiable to incorporate the new data without the hard core being affected;

3) provide new information that could seriously affect the hard core of the program to the extent of having to propose a new program.

The experimental data of the CTT have allowed the approach to act as a heuristic of the program as it has identified problems and constructed auxiliary hypotheses to solve them. The CTT shows how the program can be completed so it can explain and predict new real phenomena. According to Lakatos, the heuristic consists of a set of partially articulated suggestions and indications of how to 
change and develop the program, and how to modify and refine the protective belt. As indicated by Chalmers (1982: 184) the importance of the positive heuristic is emphasized in the program methodology because it determines the degree to which the program is organized to guide future investigations; therefore new theories and approaches ensure some type of success in future investigations. Scientific research programs exist in society because they serve a definite function in the world of knowledge. But "[...] programmes may take decades before they get off the ground and become empirically progressive. Criticism is not a Popperian quick kill, by refutation.

Important criticism is always constructive" (Lakatos 1978: 6). In a program, progress is often made through a constantly refined statement of hypothesis.

In science, problems are seen as signs of conflict between theory and practice. This can be due to some failure in the theory or in the way the experiment was carried out. Researchers, in such cases, offer a hypothesis as a solution to this kind of problem. Lakatos argues that even if a hypothesis has been shown to be false it should not be thrown away, but kept for a little longer. To this statement Chalmers (1982: 117) replies that the development of the program not only will suppose the addition of opportune auxiliary hypotheses, but also the development of experimental techniques. In this sense Cabré (2003: 179) has observed that "If for Wüster the main object of terminology was to avoid ambiguity in international intra-professional communication, it is obvious that the scope of terminology was limited to the standardisation of concepts [...] and the standardisation of its designation in different languages." For the CTT, Wüster's object of terminology is problematic to the extent that the GTT is reductive and focuses on standardization: it is reductive because of the general view of the terminological unit and its normativity and because of the importance of standardization in international professional communication (Cabré 2000: 11-12). Based on the fact that scientific and technical terminology in professional texts has the function of representing and communicating specialized knowledge, terminology should appear at different levels of specialization. This view of terminology can be briefly summarized as terminology proper or technical lexicon, semispecialized or semitechnical lexicon (terminology between general and specialized language), and general lexicon. The CTT does not limit its methodology to the study of the technical lexicon, as the GTT does; instead it contemplates the diversity of these levels for the different objectives of terminology products. Consequently, what the CTT opportune auxiliary hypothesis offers as a contribution is a descriptive approach to terminology, firmly based on a linguistics standpoint, in order to develop different kinds of terminological applications for different terminology users.

Although the CTT recognizes that traditional terminology has developed a systematic set of principles (Cabré 1999: 109), empirical data have allowed the CTT to state that even though traditional theory is internally consistent, it cannot describe real data in all their density and in all kinds of communication situations. Instead the CTT explores a possible solution by outlining the basis for a new theory of terminology which would account for term complexity based on the fact that knowledge is not homogeneous. Accordingly, terms should be studied in a situation of natural communication and from a social perspective and therefore provide "[...] terminological data in their natural environment in discourse, with variations according to the different functional registers of specialized communication, [...]" (Cabré 2003: 178). The CTT or the "theory of doors," as defined by Cabré (2000), is a theory that enables a multidimensional treatment of terms. This proposal is achievable because the CTT acknowledges that:

[...] term and word are not different units: we start from the CTT [...], which states that the lexical unit (LU) is not per se either word or term, but rather a lexical form associated to all information relative to the different modules of the grammar of which it participates. According to the communicational situation in which it is used, it either activates or not a specialized value. (Adelstein and Cabré 2002: 5).

Therefore, the CTT can account for terminological variants, contextual diversity, and pragmatic features. In this new approach, Cabré (2001: 33) considers term variation a fundamental issue. Terminology variation is important from the practical point of view for retrieving information, describing terms, providing technical writers and translators with real contexts and knowing which terms are actually used in specialized texts in order to make decisions for term standardization. 
Although terminology variation is at the heart of the CTT, this does not mean, according to Candel (2004), that Wüster's GTT does not recognize usage and linguistic variation. Taking into account Wüster's Einführung in die allgemeine Terminologielehre und terminologische Lexikographie [Introduction to the General Theory of Terminology and Terminological Lexicography], Candel gives evidence of this fact by demonstrating that semasiology was not ignored in his work, biunivocity was not a general rule for terminology work, a kind of polysemy was demonstrated, monosemy was not necessary, synonymy was attested in different levels of language and degrees of specialization, and moreover, standardization has its limits.

\section{Two Preliminary Conclusions}

Two initial conclusions can be drawn from this study. First, the CTT considers the fact that terminology users do not always adopt standardized terms and therefore the CTT's methodology provides the possibility of documenting all terms used to designate the concepts in a discipline as a descriptive approach to terminology work. In this way, it can justify terminology variation, contextual diversity, and pragmatic features. The CTT's contribution gives the different strands of terminology the opportunity to be combined in a model called the "theory of doors": "This model attempts to represent the plural, but not simultaneous, access to the object; and in such a way that, whether starting from the concept or the term or the situations, the central object, the terminological unit, is directly addressed" (Cabré 2003: 186). Second, the characterization of terminology as a research program is fundamental to understand how the theories of this discipline survive verification and falsification. The scientific research program reflects the active aspect of the discipline and explains the current state of development of terminology. In this sense, considering terminology as a research program reflects its dynamic aspect better than other analysis possibilities.

Lakatos agreed with Kuhn that the best way to analyze the growth of a discipline is to see it as a set of theories rather than as a single theory. Theories help scientists organize and understand observations; they also help to predict and create future ones. By studying the current state of terminology theory from the perspective of the philosophy of science, we will eventually achieve a more accurate picture of the state of development of terminology. We have used Lakatos's program to shed light on the overall structure of terminology. Lakatos's schema has served to highlight and rescue the distinctive and contributory aspects of the different approaches to terminology for the development of the discipline. In this text we have emphasized the contribution of the CTT proposed by Cabré (1999).

Since the success of unifying the different approaches to terminology may be controversial, understanding the overall structure of the discipline may clarify their drawbacks as well as their advantages. Our interest in Lakatos's scientific research program is based on its structural character and on its applicability to terminology research. Asking what the "heuristic" of a traditional terminology approach involves enables us to see that the majority of the approaches attempt to demonstrate that a theoretical equilibrium will be obtained; therefore these different approaches are unified in more than just their common hypothesis but in a terminology research program.

\section{REFERENCES}

Adelstein, A. and M. T. CABré (2002): “The Specificity of Units with Specialized Meaning: Polysemy as Explanatory Factor", DELTA [online] 18, p. 1-25, retrieved March 1, 2005, from:

$<$ http://www.scielo.br/scielo.php?script=sci_arttext\&pid=S0102-44502002000300003\&lng=pt\&nrm=iso >, ISSN 0102-4450.

Blanchon, E. (2004): "Report on the Second International Terminology Conference - CIT 2003. Terminology: The State of the Theories", Terminology 10-2, p. 337-340.

BudIN, G. (2001): "A Critical Evaluation of the State-of-the-art of Terminology Theory", Terminology Science \& Research 12-112, p. 7-23.

CABRÉ, M. T. (1999): La terminología: Representación y comunicación. Elementos para una teoría de base 
comunicativa y otros artículos, Barcelona, Institut Universitari de Lingüística Aplicada.

CABRÉ, M. T. (2000): «Terminologie et linguistique: La théorie des portes », Terminologies Nouvelles 21, p. 1015.

CABRÉ, M. T. (2001): "Consecuencias metodológicas de la propuesta teórica”, in La terminología científico-técnica: reconocimiento, análisis y extracción de información formal y semántica, p. 27-36, Barcelona, IULA-UPF.

CABré, M. T. (2003): "Theories of Terminology: Their Description, Prescription and Explanation", Terminology 92, p. 163-199.

CANDEl, D. (2004): "Wüster par lui-même", in CORTÈs, C. (ed.) : Des fondements théoriques de la terminologie, Cahier du C.I.E.L., Paris, Université Paris 7, p. 15-31.

CHALMERS, A. (1982): ¿Qué es esa cosa llamada ciencia? Una valoración de la naturaleza y el estatuto de la ciencia y sus métodos, translation by PÉREZ SEDEÑo, E., Madrid, Siglo XXI de España editores.

KuHN, T. (1962): The Structure of Scientific Revolutions, Chicago, University of Chicago Press.

Lakatos, I. (1970): "Falsification and the Methodology of Scientific Research Programmes", in LaKatos, I. and

A. Musgrave (eds.): Criticism and the Growth of Knowledge. Proceedings of the International Colloquium in the Philosophy of Science 4, Cambridge, Cambridge University Press, p. 91-195.

LaKatos, I. (1978): The Methodology of Scientific Research Programmes, Cambridge, Cambridge University Press.

LAKATOS, I. and A. MusgraVe (1970): Criticism and the Growth of Knowledge. Proceedings of the International Colloquium in the Philosophy of Science 4, Cambridge, Cambridge University Press.

POPPER, K. R. (1962): Conjectures and Refutations: The Growth of Scientific Knowledge, New York, Basic Books. WÜSTER, E. (1989): Introduction to the General Theory of Terminology and Terminological Lexicography, translation by BRENT, E. and R. AlBER-DEWOLF, unpublished document (original work in German published in 1979), Québec, Secrétariat d'État, Office de la langue française, Université Laval-GIRSTERM. 